\title{
DEBRIS-COVERED GLACIERS AND ROCK GLACIERS IN THE NANGA PARBAT HIMALAYA, PAKISTAN
}

\author{
BY \\ JOHN F. SHRODER ${ }^{1}$, MICHAEL P. BISHOP ${ }^{1}$, LUKE COPLAND $^{2}$ AND VALERIE F. SLOAN $^{3}$ \\ ${ }^{1}$ Department of Geography and Geology, University of Nebraska at Omaha, USA \\ ${ }^{2}$ Department of Geology, University of Alberta, Edmonton, Canada \\ ${ }^{3}$ INSTAAR, University of Colorado, Boulder, USA
}

Shroder, John F., Bishop, Michael P., Copland, Luke and Sloan, Valerie F., 2000: Debris-covered glaciers and rock glaciers in the Nanga Parbat Himalaya, Pakistan. Geogr. Ann., 82 A (1): 17-31.

\begin{abstract}
The origin and mobilization of the extensive debris cover associated with the glaciers of the Nanga Parbat Himalaya is complex. In this paper we propose a mechanism by which glaciers can form rock glaciers through inefficiency of sediment transfer from glacier ice to meltwater. Inefficient transfer is caused by various processes that promote plentiful sediment supply and decrease sediment transfer potential. Most debris-covered glaciers on Nanga Parbat with higher velocities of movement and/ or efficient debris transfer mechanisms do not form rock glaciers, perhaps because debris is mobilized quickly and removed from such glacier systems. Those whose ice movement activity is lower and those where inefficient sediment transfer mechanisms allow plentiful debris to accumulate, can form classic rock glaciers.

We document here with maps, satellite images, and field observations the probable evolution of part of a slow and inefficient ice glacier into a rock glacier at the margins of Sachen Glacier in c. 50 years, as well as several other examples that formed in a longer period of time. Sachen Glacier receives all of its nourishment from ice and snow avalanches from surrounding areas of high relief, but has low ice velocities and no efficient system of debris removal. Consequently it has a pronounced digitate terminus with four lobes that have moved outward from the lateral moraines as rock glaciers with prounced transverse ridges and furrows and steep fronts at the angle of repose. Raikot Glacier has a velocity five times higher than Sachen Glacier and a thick cover of rock debris at its terminus that is efficienctly removed. During the advance stage of the glacier since 1994, ice cliffs were exposed at the terminus, and an outbreak flood swept away much debris from its margins and terminus. Like the Sachen Glacier that it resembles, Shaigiri Glacier receives all its nourishment from ice and snow avalanches and has an extensive debris cover with steep margins close to the angle of repose. It has a high velocity similar to Raikot Glacier and catastrophic breakout floods have removed debris from its terminus twice in the recent past. In addition, the Shaigiri terminus blocked the Rupal River during the Little Ice Age and is presently being undercut and steepened by the river. With higher velocities and more efficient sediment transfer systems, neither the Raikot nor the Shaigiri form classic rock-glacier morphologies.
\end{abstract}

\section{Introduction}

Glaciers in the Himalaya are characteristically covered with thick debris because of the large volumes of ice avalanche and rock fall to the glacier surface from steep surrounding slopes. Kick (1962) noted that Adolf Schlagintweit first used the term firnkessel glaciers in 1856 for the types of glaciers in High Asia that are fed predominantly by avalanches from the high cliffs, as opposed to the firnmulden types in the Alps that are nourished by slow ice flow from a firn field. Because of the irregular or punctuated delivery of ice avalanches, the mass balance of the Himalayan glaciers is thought to be much more irregular than elsewhere, with the result that considerable variation from one glacier to another can occur in advance, retreat, ice buildup, or downwasting (Mercer 1963, 1975a, b; Mayewski and Jeschke 1979). In general, however, most of the glaciers of High Asia have receded since the second half of the nineteenth century, or the Little Ice Age. A few glaciers, such as the Shaigiri and Sachen on Nanga Parbat, were noted by Kick (1962) to have hardly changed at all since they were first described in the last century. $\mathrm{He}$ called these two dam glaciers that rest on their own bed of debris and appear to deposit till that accretes below the ice, raising it up until the ice stands well above the valley bottom, and forms strong lateral moraines close to the angle of repose, with prominent ablation valleys on either side.

In cases where debris cover on glaciers is thick and where glacier ice motion is limited, classic rock glaciers may be produced at Nanga Parbat. These landforms have longitudinal and transverse ridges and furrows, and steep termini at the angle of repose. The history of rock-glacier research is replete with: (1) appeals to dogmatic exclusion of one landform or another from the ranks of acceptable rock glaciers (Barsch 1996); (2) precise descriptions of morphologic characteristics necessary to define a 'classic' rock glacier (Wahrhaftig and Cox 1959); (3) arguments concerning mechanics of motion (Whalley and Martin 1992); and (4) some recognition of ideas of polygenesis or the continua of 
Table 1. Sediment transfer efficiency from glacier ice to meltwater in the Nanga Parbat Himalaya.

\begin{tabular}{ll}
\hline Higher transfer efficiency & Lower transfer efficiency \\
\hline Limited sediment & Plentiful sediment \\
Plentiful cold-based ice & Little cold-based ice \\
Little warm-based ice & Plentiful warm-based ice \\
Much firn-field nourishment & Much avalanche supply \\
Limited debris sources & Plentiful debris sources \\
Thin supraglacial debris & Thick supraglacial debris \\
Vegetated side slopes & Unvegetated slopes \\
Tectonically stable & Tectonically active \\
& \\
\hline Increased & Decreased \\
transfer en potential & transfer potential \\
\hline
\end{tabular}

\begin{tabular}{|c|c|}
\hline \multicolumn{2}{|c|}{ Valley and ice characteristics } \\
\hline Steep terminus zone & Gentle terminus zone \\
\hline Narrow valley at terminus & Wide valley at terminus \\
\hline Lower ice velocity at terminus & $\begin{array}{l}\text { Higher ice velocity at } \\
\text { terminus }\end{array}$ \\
\hline \multicolumn{2}{|c|}{ Water characteristics } \\
\hline Large meltwater discharge & Small meltwater discharge \\
\hline $\begin{array}{l}\text { Migratory terminus drainage } \\
\text { portal }\end{array}$ & $\begin{array}{l}\text { Static terminus drainage } \\
\text { portal }\end{array}$ \\
\hline Common outburst floods & Rare outburst floods \\
\hline Trunk river at terminus & No trunk river at terminus \\
\hline
\end{tabular}

forms and generic applications of the terminology (Giardino et al. 1987). As Vitek and Giardino (1987) have pointed out, however, morphology is not necessarily diagnostic of motive mechanism, as the term rock glacier is generic not genetic. Most authors agree, however, that whatever the motive mechanism, thick debris covers are characteristic. Furthermore, most rock glaciers have low ice velocities (c. $1 \mathrm{~m} \mathrm{a}^{-1}$ or less). Low ice velocities, which decrease gradually downward into the mass, tend to form the typical transverse ridges and furrows. Also with low velocities, steep fronts tend to pile up at the angle of repose, although the mechanisms of this process are controversial (Whalley and Martin 1992). Once formed, rock glaciers tend to equilibrate to a nearly static landform without significant change thereafter. High ice velocities tend to produce classic ice glacier forms, but not rock glaciers. Under certain special circumstances, rock glaciers are seen to develop from debris-covered glaciers in the western Himalaya.

Glaciers in the western Himalaya have high variability of debris-load (Bishop et al. 1995) and varying efficiencies of sediment transfer from their termini to other transport pathways such as rivers (Shroder et al. 1996). Based upon field investigations and interpretation of satellite imagery, it appears that the most efficient sediment transfer (Table 1) occurs in those valleys where there sediment is limited by: (1) a high ratio between higher altitude, cold-based, protective ice and lower altitude, warm-based, erosive ice which reduces sediment supply; (2) dominant firn-field glacier nourishment, and therefore maximum ice flux with minimum supraglacial debris cover; (3) limited debris sources and debris feed to the glacier; (4) a relatively thin supraglacial debris cover; (5) vegetated side slopes that retain sediment; and (6) tectonic stability that reduces seismicity and fault shattering of rocks. Sediment transfer potential is increased: (7) in steep terminus zones; (8) with lower ice velocities; and (9) where a narrow valley occurs in the glacier terminus zone that restricts the moraine and enables its removal. Such transfer is also increased where: (10) high meltwater discharges occur; (11) a laterally migratory subglacial drainage portal occurs at the terminus; (12) outburst floods remove sediment; and (13) a trunk river removes sediment at the terminus. On the other hand, transfer inefficiency could allow glacier debris to accumulate and form rock glaciers where only limited ice motion occurs beneath the debris.

In the course of work on the Nanga Parbat Project (Bishop et al. 1998a), in which measurements of long- and short-term incision and denudation are paramount, we recognized that most of the high velocity, transfer efficient ice glaciers of Nanga Parbat do not form rock glaciers. Sachen Glacier, on the other hand, is one of the least efficient glaciers on the mountain, and does have several rock glaciers associated with it, which suggested a possible genetic relation of interest to us. The aims of this paper are: (1) to describe and characterize representative conditions of glacier debris loads and ice velocities of the Raikot and Shaigiri glaciers, together with the characteristics of efficient sediment transfer that control their form as debris-covered glaciers without associated rock glaciers; and (2) to contrast the debriscovered Raikot and Shaigiri glaciers with the more thickly debris-covered Sachen Glacier that has low velocity, inefficient sediment transfer, and associated rock glaciers. Precise motive mechanisms are not implied; nor are aspects of glacial ice versus permafrost (Whalley and Martin 1992). Nevertheless, the surficial characteristcs of part of Sachen Glacier that are described here have the 
Fig. 1. Index map of study area in western Himalaya (Karakoram and Nanga Parbat Himalaya) of Pakistan.

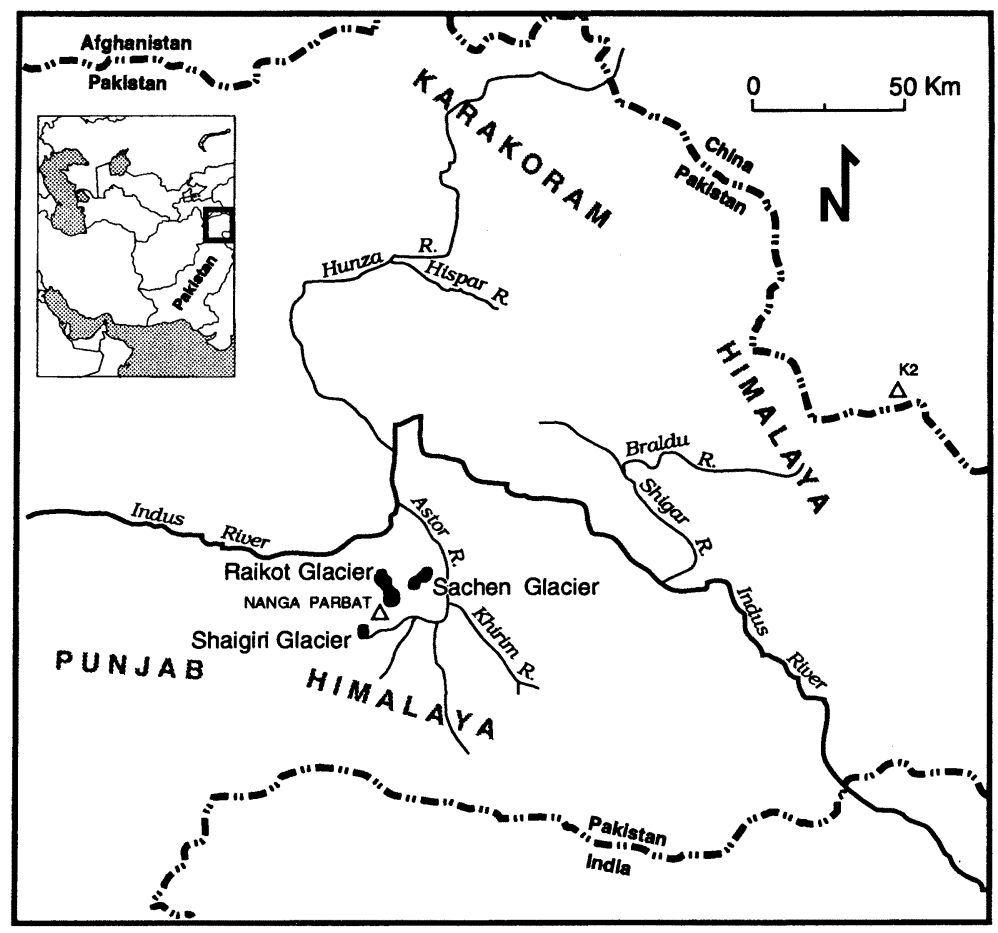

morphology of rock glaciers and may add understanding to the long-standing enigma of polygenetic rock glaciers.

\section{Study area}

Nanga Parbat is located in the Himalaya of northern Pakistan (Fig. 1), and is the ninth highest mountain in the world at $8125 \mathrm{~m}$. It is heavily ice covered in its upper reaches by 69 separate glaciers which cover an area of $302 \mathrm{~km}^{2}$ and have an estimated volume of $25 \mathrm{~km}^{3}$ (Kick 1980). The mean elevation of the glaciers is $5140 \mathrm{~m}$ on the north side of the mountain, and $4720 \mathrm{~m}$ on the south side, with the lowest ice reaching down to $c .3000 \mathrm{~m}$. The mountain is strongly influenced by orographic precipitation as it is the first major topographic barrier to monsoon precipitation that travels northwards from the Indian Ocean and Arabian Sea. At higher elevations above $5000 \mathrm{~m}$, the summer monsoon precipitation falls as snow. In winter, westerly storms also provide some snow. Precipitation is less than $120 \mathrm{~mm} \mathrm{a}^{-1}$ at elevations below $2500 \mathrm{~m}$, but rises to more than $8000 \mathrm{~mm} \mathrm{a}^{-1}$ at elevations above $4500 \mathrm{~m}$ (Kick 1980).
Three of the glaciers on Nanga Parbat provide the focus of this paper: Raikot, Shaigiri, and Sachen (Fig. 1). Raikot Glacier flows from the north side of the mountain, and is surrounded by steep slopes that provide frequent snow and ice avalanches onto the glacier surface. Icefalls connect the accumulation zone with the ablation zone, which consists of a relatively low-gradient $\left(9^{\circ}\right)$ tongue. Sachen Glacier forms the main ice mass on the eastern side of the mountain, and is physically similar to Shaigiri Glacier on the south side. Both of these glaciers have relatively wide and flat accumulation zones at elevations above $5000 \mathrm{~m}$ and are somewhat unusual because their accumulation and ablation zones are not physically connected. Ice and snow avalanches from the upper accumulation zone are the only way that mass is provided to the lower ablation zone. As is characteristic of most Himalayan glaciers, and all of the glaciers discussed here, their ablation zones are heavily debris covered by material up to $4 \mathrm{~m}$ thick. This supraglacial debris reduces ablation, and allows the glaciers to extend to lower elevations than would be otherwise possible. 


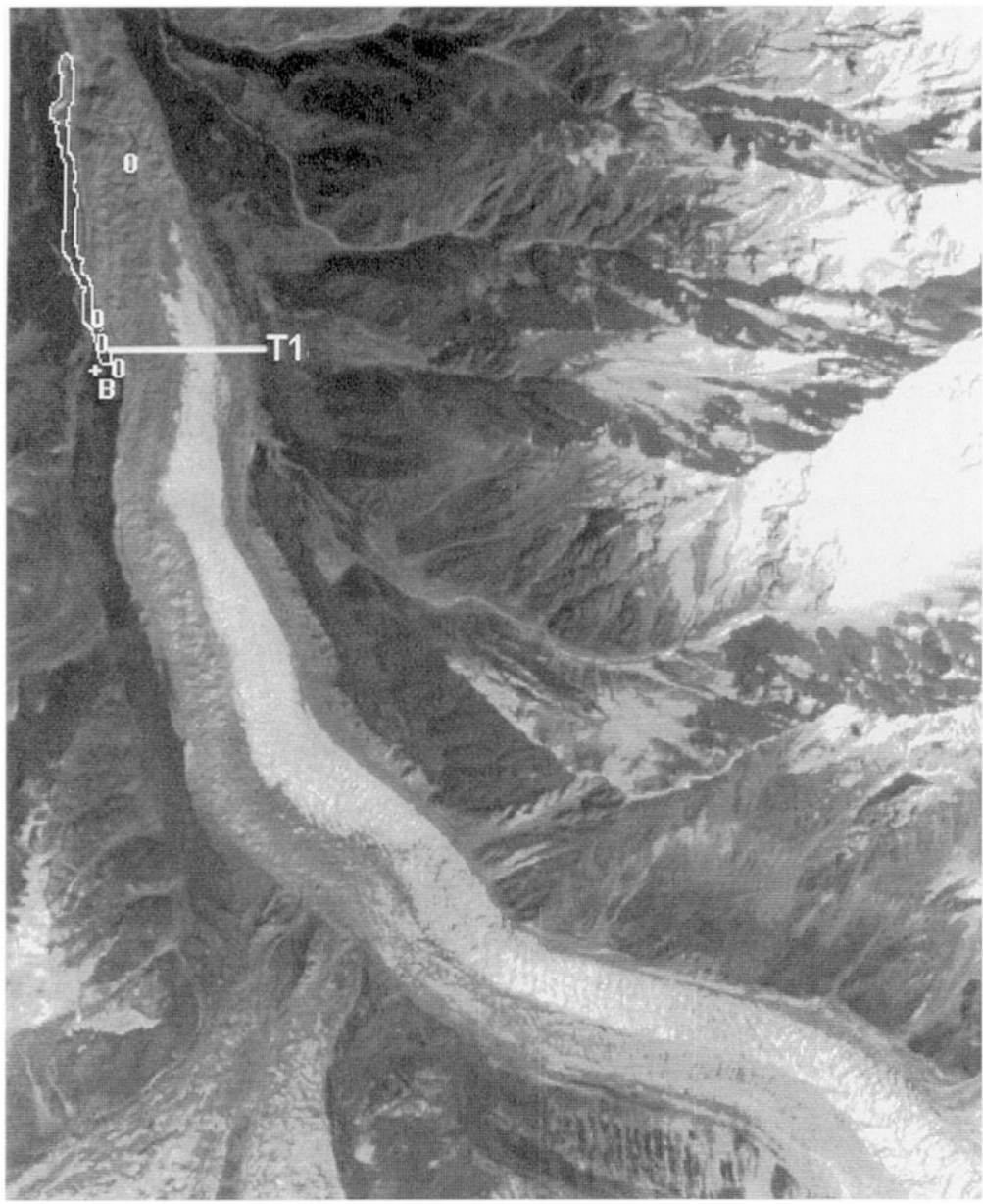

Fig. 2. SPOT panchromatic image of Raikot Glacier in 1991 on the north side of Nanga Parbat. The image is annotated as follows: $+\mathrm{B}-$ location of base station in 1996 for measuring velocity and samples of debris depths along transects. T1 is the measurement transect. Open circles are portals of breakout floods. The floodway is illustrated by light lines. The glacier is $\sim 750$ $\mathrm{m}$ wide near the transect.

\section{Methodology \\ Data acquisition and processing}

Fieldwork was conducted intermittantly during the summers of 1984, 1993, 1995, 1996, and 1997. Data collection consisted of measuring supraglacial debris depths and ice velocities, as well as dendrogeomorphological assessment (Spencer 1985; Shroder, et al. 1996). Slope profiles and ground photography were also used to document landform characteristics and landscape conditions. All information obtained in the field was georeferenced using the technology of the global positioning system (GPS) to $c . \pm 30 \mathrm{~m}$ accuracy.

Measurements of surface velocity and supraglacial debris depths were made along multiple tran- sects in the ablation areas of the Raikot and Shaigiri glaciers in summer 1996. One representative transect for each glacier is reported here (Fig. 2, Table 2; Fig. 3, Table 3). Velocities were determined by surveying the location of markers painted on large boulders across each transect at the start and end of 4-6 day periods. A Geodimeter Total Station 400 electronic theodolite with an accuracy of $\pm 11-$ $23 \mathrm{~mm}$ over the distances surveyed was used for this. Debris depths were determined by digging through and measuring the supraglacial debris layer to solid ice. Where the debris was too thick to enable the underlying ice to be reached, a debris depth of $1.5 \mathrm{~m}$ was recorded. The debris depth chosen was based on observations at the top of exposed ice cliffs at the margins and over the surface of the glaciers. 
Fig. 3. Map of Shaigiri Glacier taken from Finsterwalder (1937) and SPOT image of 1996. T1 (Table 3), $\mathrm{T} 2$, and $\mathrm{T} 3$ are measurement transects. The lower part of the icefall that was mapped as ice by Finsterwalder in 1937 is bare rock in 1996.

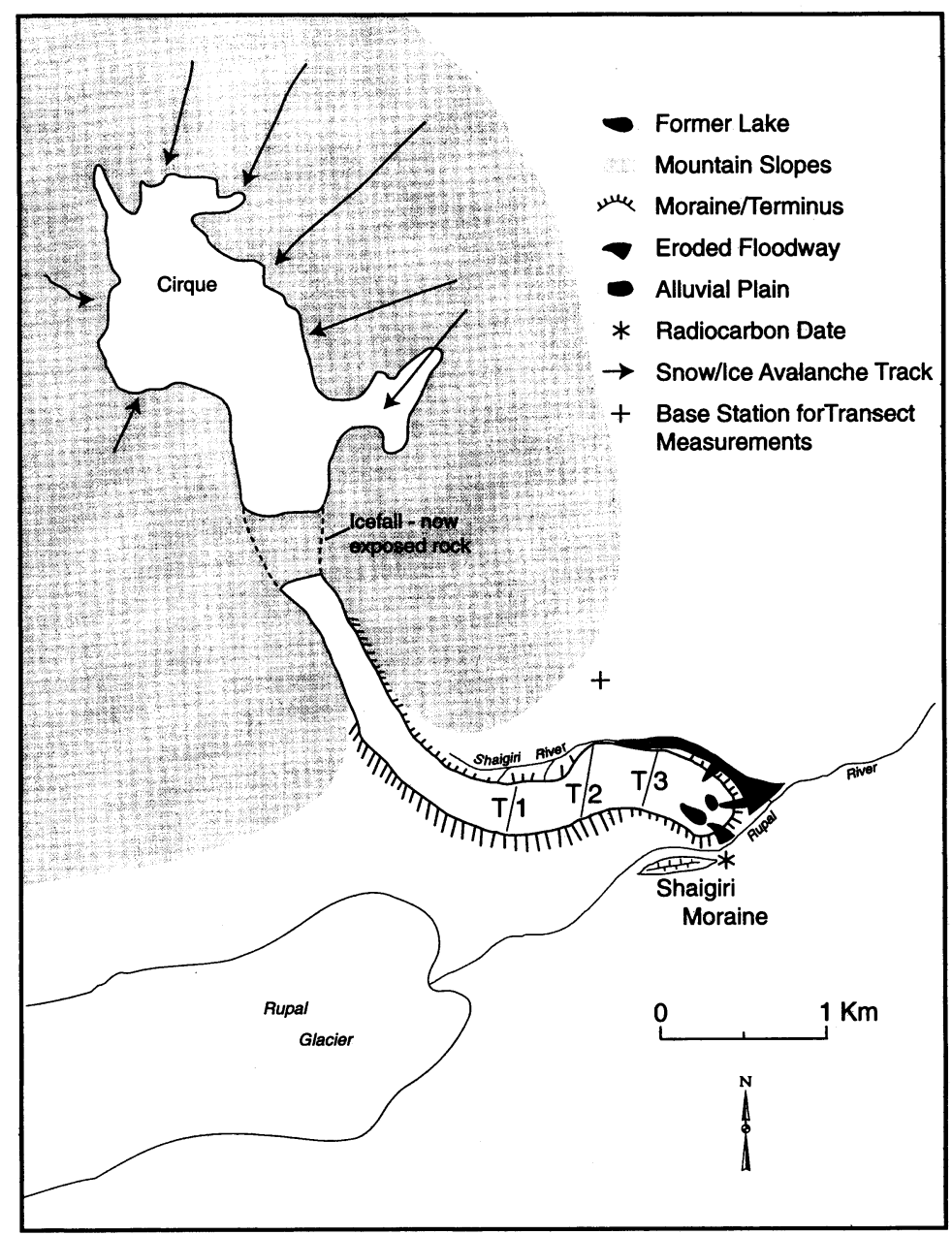

Table 2. Velocities and debris depths on transect T1 across Raikot Glacier.

\begin{tabular}{lccccccc}
\hline Point & $\begin{array}{c}\text { Distance along } \\
\text { transect }(\mathrm{m})\end{array}$ & $\begin{array}{c}\text { Debris } \\
\text { depth }(\mathrm{m})\end{array}$ & $\begin{array}{c}\text { Veiocity } \\
\left(\mathrm{cm} \text { day }^{-1}\right)\end{array}$ & Point & $\begin{array}{c}\text { Distance along } \\
\text { transect }(\mathrm{m})\end{array}$ & $\begin{array}{c}\text { Debris } \\
\text { depth }(\mathrm{m})\end{array}$ & $\begin{array}{c}\text { Velocity } \\
(\mathrm{cm} \text { day }\end{array}$ \\
\hline $1-1$ & 18.0 & 0.55 & 9.3 & $1-12$ & 334.6 & 0.06 & 15.9 \\
$1-2$ & 39.9 & 0.75 & 8.3 & $1-13$ & 372.4 & 0.02 & 18.0 \\
$1-3$ & 61.9 & 0.75 & 9.7 & $1-14$ & 403.6 & 0.00 & 15.2 \\
$1-4$ & 76.8 & 0.25 & 10.9 & $1-15$ & 428.3 & 0.02 & 15.9 \\
$1-5$ & 94.7 & 0.70 & 10.7 & $1-16$ & 458.0 & 0.00 & 16.2 \\
$1-6$ & 124.8 & 0.04 & 12.3 & $1-17$ & 562.0 & 0.05 & 16.1 \\
$1-7$ & 168.1 & 0.20 & 13.8 & $1-18$ & 603.2 & 0.05 & 6.5 \\
$1-8$ & 198.4 & 0.08 & 11.9 & $1-19$ & 646.5 & 0.05 & 12.2 \\
$1-9$ & 219.9 & 0.18 & 12.0 & $1-20$ & 687.7 & 0.04 & 11.2 \\
$1-10$ & 253.8 & 0.08 & 15.2 & $1-21$ & 718.1 & 0.03 & 6.2 \\
$1-11$ & 297.7 & 0.05 & 16.1 & $1-22$ & 731.6 & 0.08 & 5.3 \\
& & & & Mean velocity & & 12.2 \\
\hline
\end{tabular}



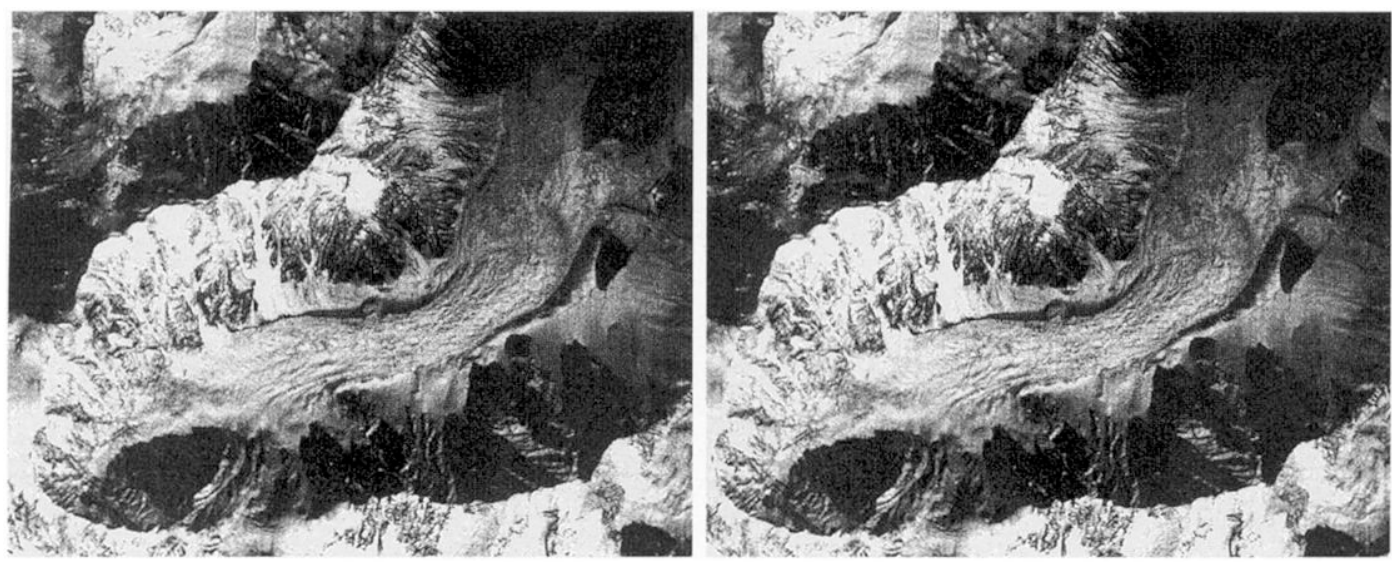

Fig. 4. Stereopair of satellite images of Sachen Glacier. These images were generated from a digital elevation model derived from two SPOT images taken in October, 1996, following a light snowfall. Because of the mathematical transformations of the data that were required to produce stereo imagery of this kind, some of the cliffed slopes are too steep, and the lower regions of Sachen Glacier near the edge of the image actually appear to rise gently, where they actually decline gently. Nevertheless, the overall configuration of Sachen Glacier and the rock glaciers projecting from it are clear. Compare with Fig. 7 for locations.

Velocities and debris depths were not measured at Sachen Glacier (Fig. 4) because prior observations by Finsterwalder $(1936,1937)$ and Kick (1962, and unpublished data) indicated a low index of activity that was of low interest in our attempt to understand the more rapid rates of denudation from Nanga Parbat. The glacier was judged, however, as highly useful in understanding inefficient sediment transfer, but debris depths near the terminus were greater than we could measure. Furthermore, the glacier forefield of Sachen is composed of large masses of the Rama moraine that is little eroded since deposition, in contrast to the strongly eroded forefields of Raikot and Shaigiri where almost all moraine has been removed.

SPOT Panchromatic data acquired on 31 October 1991, with a spatial resolution of $10 \mathrm{~m}$, were used to map debris load variations on each glacier. Specifically, satellite imagery and artificial neural network (ANN) technology were used to classify categories of debris-load classes for each glacier based upon surface reflectance variations and environmental relationships (Bishop et al. 1999). Bishop et al. $(1995,1998 \mathrm{~b})$ have demonstrated that debris-load variability on Himalayan glaciers is relatively high and that supraglacial characteristics can be accurately characterized and mapped using robust, quantitative, remote-sensing analysis and pattern-recognition approaches. We use high resolution panchromatic satellite data and ANN techniques to produce accurate debris-load maps that depict the spatial variability of debris-load characteristics (Figs 5 and 6).

We specifically utilized a feedforward ANN to classify each glacier surface, as ANNs offer numerous advantages over conventional classification algorithms, including minimal training, generalization, non-linear recognition capabilities, and classification uncertainty analysis (Hepner et al. 1990;

Table 3. Velocities and debris depths on transect T1 across Shaigiri Glacier.

\begin{tabular}{|c|c|c|c|}
\hline Point & $\begin{array}{l}\text { Distance along } \\
\text { transect }(\mathrm{m})\end{array}$ & $\begin{array}{c}\text { Debris } \\
\text { depth }(m)\end{array}$ & $\begin{array}{l}\text { Velocity } \\
\left(\mathrm{cm}^{-1 a y}{ }^{-1}\right)\end{array}$ \\
\hline $1-1$ & 35.0 & 1.00 & 4.2 \\
\hline $1-2$ & 66.8 & 1.20 & 6.0 \\
\hline $1-3$ & 92.4 & 1.00 & 8.3 \\
\hline $1-4$ & 118.3 & 1.00 & 8.8 \\
\hline $1-5$ & 152.8 & 0.80 & 11.2 \\
\hline $1-6$ & 177.8 & 0.38 & 11.0 \\
\hline $1-7$ & 215.6 & 0.55 & 12.4 \\
\hline $1-8$ & 243.5 & 0.40 & 14.8 \\
\hline $1-9$ & 265.2 & 0.50 & 13.3 \\
\hline $1-10$ & 288.9 & 1.50 & 13.8 \\
\hline $1-11$ & 325.4 & 1.50 & 12.7 \\
\hline $1-12$ & 357.1 & 0.75 & 14.0 \\
\hline $1-13$ & 409.1 & 0.60 & 14.1 \\
\hline $1-14$ & 444.6 & 1.50 & 15.7 \\
\hline $1-15$ & 481.0 & 1.50 & 14.8 \\
\hline \multicolumn{3}{|c|}{ Mean velocity } & 11.7 \\
\hline
\end{tabular}


Fig. 5. ANN classification of debris loads on Raikot Glacier. Close comparison with Fig. 8 allows a qualitative comparison between classification results and the oblique photograph. The ANN classification is generally reliable, except directly on the margins of the terminus where ice slopes are steep and shadowed.

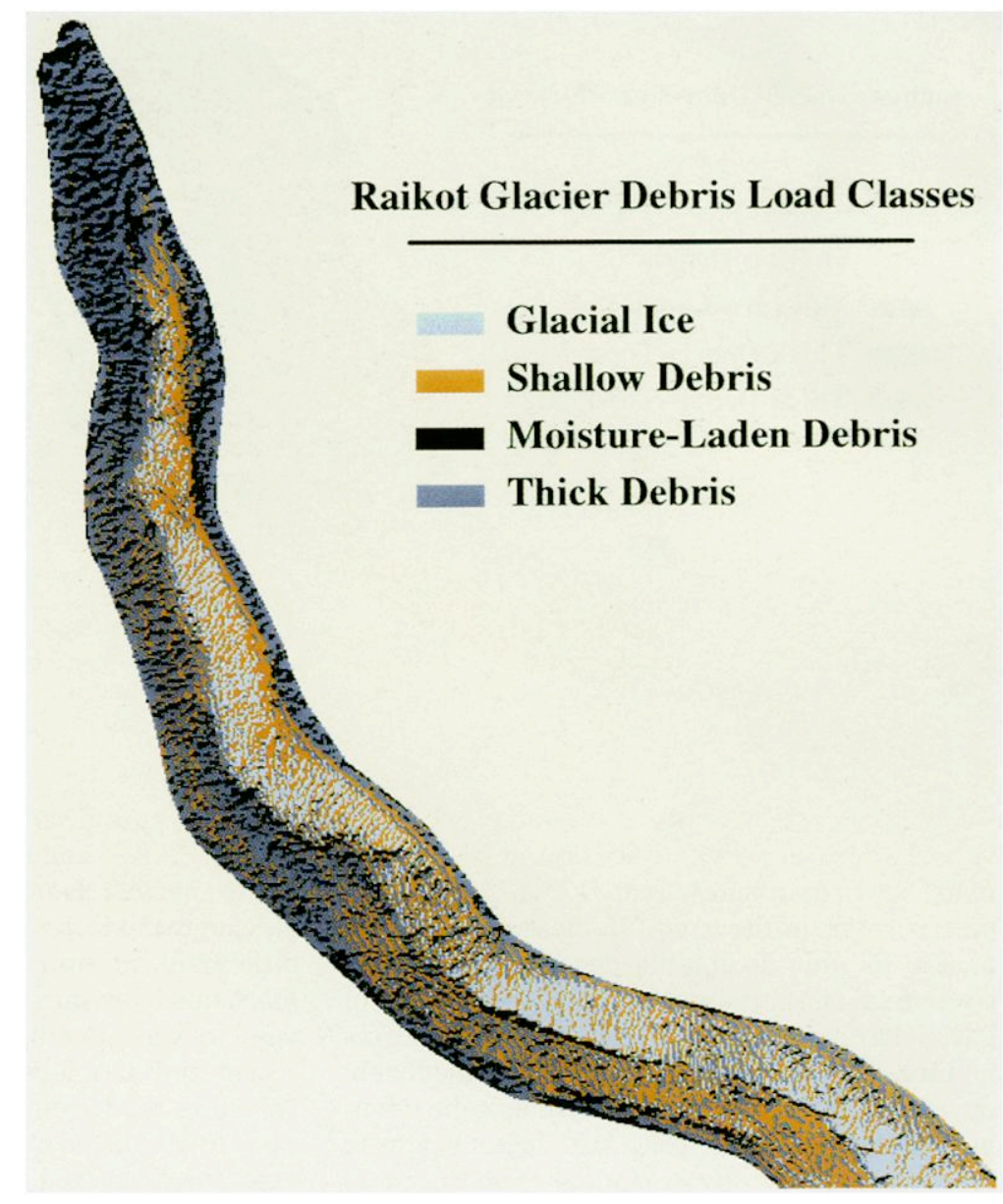

Gong and Chen 1996). These techniques may be unfamiliar to many geoscientists but afford valuable insights nonetheless (Rumelhart and McClelland 1986; Sui 1994). A C++ program was written that implements the back-propagation training algorithm, and enabled us to evaluate the multi-layer feedforward ANN.

In our analysis, the input layer consisted of nine input nodes, one hidden layer, and an output layer made up of nodes corresponding to debris-load classes. The input layer represented the spectral reflectance values from a $3 \times 3$ pixel area. A minimal training set was selected based upon random sampling of the glacier surface. We trained each ANN to recognize: (1) base glacier ice; (2) shallow debris on white ice; (3) moisture-laden, shallow debris; (4) thick debris-topographic high; and (5) thick debris-topographic low. ANN training parameters and structure were determined empirically. Accuracy assessment, or comparison between known ground conditions and ANN results, was also conducted to determine the validity of the classification results (Bishop et al. 1999).

Finally, the total efficiency of sediment transfer (Table 1) from glacier to meltwater was evaluated for Raikot, Shaigiri, and Sachen glaciers (Table 4), in order to differentiate between them. Only Sachen Glacier, with its associated rock glaciers, was clearly different from the other two (Fig. 7).

\section{Results and Discussion \\ Raikot Glacier}

The Raikot Glacier on the north face of Nanga Parbat begins in an ice field at $c .7700 \mathrm{~m}$ altitude, and descends $19 \mathrm{~km}$ through a firn basin at an elevation 


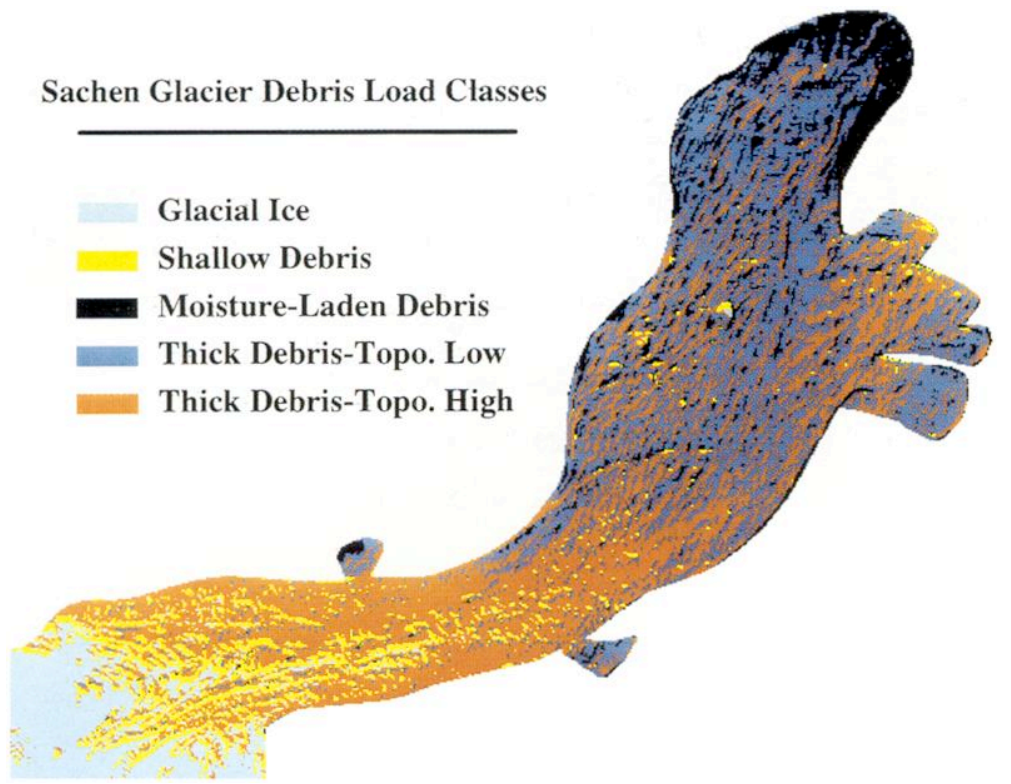

Fig. 6. ANN classification of debris loads on Sachen Glacier. The classification category of moisture-laden debris on the front of the northeastern lobe is also partly a reflection of vegetation and of shadowed slopes there. The rock glacier lobes are distinct. Comparison with Fig. 7 shows locations. of c. $5500 \mathrm{~m}$ to its terminus at $3175 \mathrm{~m}$ (Fig. 8). The glacier is one of the largest in the region, with an area of $32 \mathrm{~km}^{2}$, an equilibrium-line altitude at $c$. $4800 \mathrm{~m}$, and an accumulation/ablation area ratio of 0.60 (Gardner and Jones 1993). Large crevasses and seracs typical of plug-flow movement occur in the middle of the glacier 10-6 km above the terminus, at about the same place that debris begins to accumulate on the glacier margins (Fig. 2).

Blockschollen motion (Finsterwalder 1937) or plug-flow movement of Raikot Glacier has a rather uniform velocity distribution over most of the cross-section and a very abrupt decrease of speed near the margins. The mean surface velocity of Raikot Glacier, at a distance of $c .5 \mathrm{~km}$ from the terminus, was $37 \mathrm{~cm} \mathrm{day}^{-1}$ over seven days in midJuly 1934 (Finsterwalder 1937), and $49 \mathrm{~cm} \mathrm{day}^{-1}$ over four days in mid-August 1954 (Pillewizer 1956). Our surface velocity measurements made over four days in mid-June 1996 c. $2.5 \mathrm{~km}$ from the terminus average $12 \mathrm{~cm} \mathrm{day}^{-1}$. These variable ice velocities probably partly reflect different measurement times, as recent studies have demonstrated the strong relationship between the seasonal development of the subglacial hydrological system and ice motion rates (Harbor et al. 1997). In addition, the difference in surface velocities between our measurements and earlier ones is also likely a function of ice slowdown toward the ter- minus, as well as mass balance fluctuations, and blockage and release of subglacial drainage. It is difficult to determine conclusively which of these mechanisms is most important in explaining the velocity variations at Raikot Glacier, although the recent outbreak floods (Shroder et al. 1998) observed in the terminus region suggest that variations in subglacial hydrology are dominant. In any case, the decreased ice velocities near the terminus increase sediment transfer potential in not overwhelming the terminus area with more sediment than can be removed by existing processes (Table 1).

At c. $2.5 \mathrm{~km}$ from the terminus, debris of varying thickness completely covers the glacier surface and increases in thickness toward the glacier terminus and margins. Our measurements of debris cover (Table 2) closely resemble those of Gardner and Jones (1993) and were used to evaluate the accuracy of the ANN classifications (Fig. 5). Debris accumulations have formed close to or at the angle of repose on the margins in the past, and have then declined as the subsurface ice melted or moved along. Mattson and Gardner (1989) and Mattson et al. (1993) noted that ablation of Raikot Glacier was initially enhanced by addition of thin debris covers up to $c .1 .0 \mathrm{~cm}$. Above $3 \mathrm{~cm}$ the debris cover acts as an insulator and suppresses ablation.

Terminus fluctuations have been well document- 
Fig. 7. Simplified geomorphological map of Sachen Glacier and its four rock glaciers. 1 - West Sango rock glacier \# 1;2 - East Sango rock glacier \# 2; 3 - northwest rock glacier \# 3; avalanche rock glacier \# 4. Two ridges or kinematic waves near rock glacier \# 2 are from the original map by Finsterwalder (1937), whereas the ridge or kinematic wave between Sango Sar and rock glaciers \# 3 and \# 4 occurred in 1996.

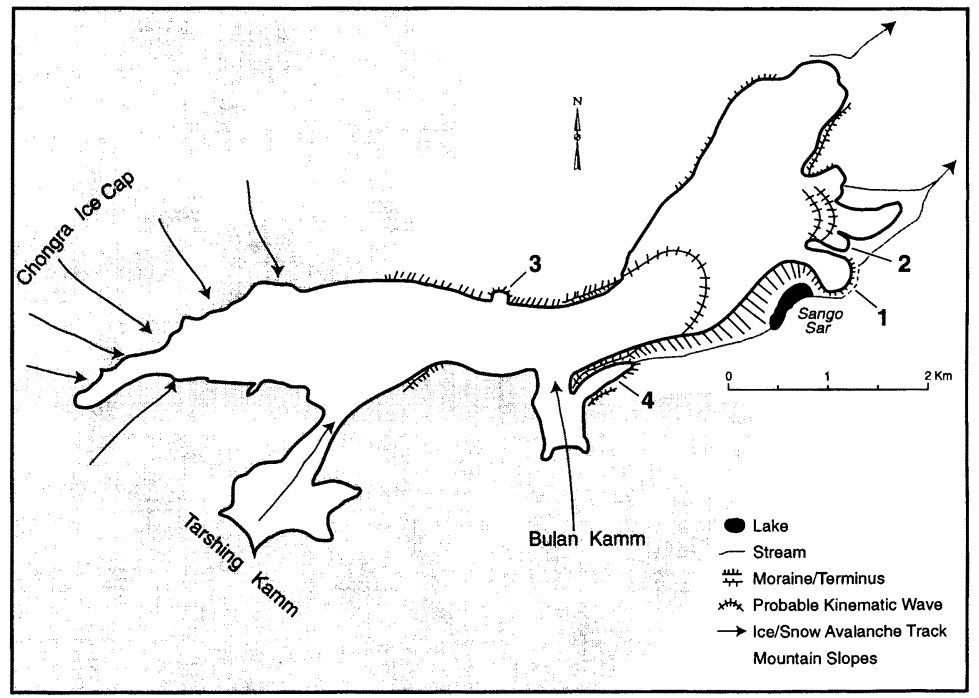

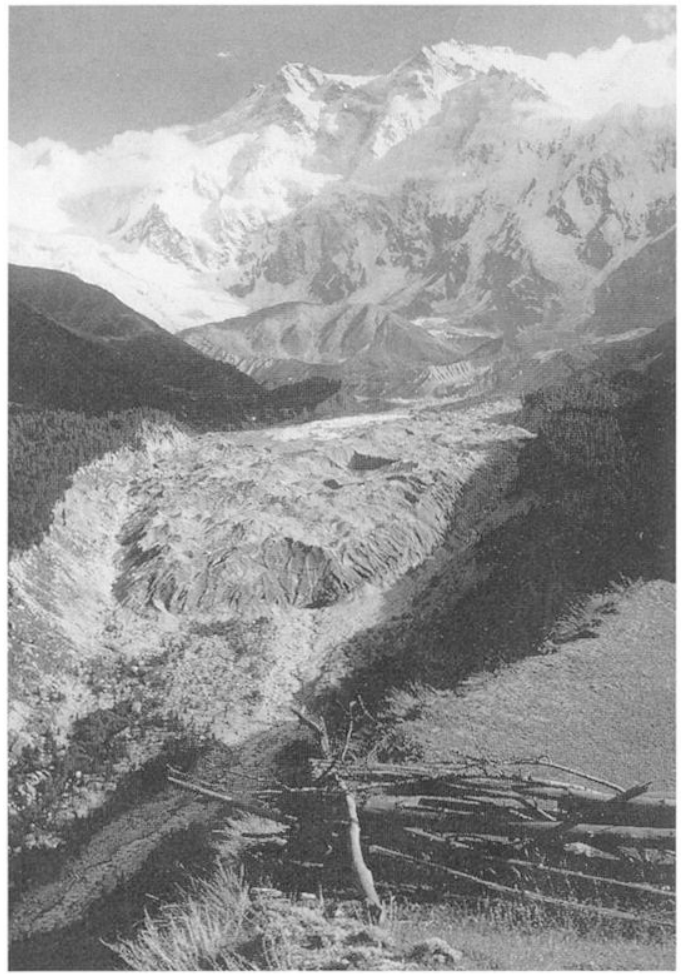

Fig. 8. Photograph looking south at Raikot Glacier terminus in 1995 following break-out flood of 1994 that removed much debris from the west (shadowed) side and forefield of the glacier. Three pressurized bursts of meltwater were distributed along the whole length of the shadowed area, and a fourth break-out portal occurred on the top of the terminus just to the left (east) of the main drainage portal and the large ice cliff above the Raikot River pictured. ed by Gardner (1986), with thinning and backwasting of $450 \mathrm{~m}$ from 1930 to 1954 and advance of 200 $\mathrm{m}$ up to the mid-1980s. The subglacial meltwater channel migrated from the east side of the terminus to the west side, then into the center, and now in the 1990 s, back to the west again.

From 1994 to 1996 the debris-covered terminus of Raikot Glacier greatly steepened and new ice cliffs appeared on the front and west sides. At the same time, Chongra Glacier, in the Rupal valley on the opposite side of the mountain, was observed to be behaving similarly, with the initiation of a new period of advance (Shroder et al. 1998). The contemporaneous response of both glaciers suggests that they were responding to an increase in mass balance on both sides of the upper mountain ridge at some time in the past.

In late 1993 or early 1994, in the midst of the renewed advance, the subglacial drainage system of Raikot Glacier became blocked c. $1.5 \mathrm{~km}$ from the terminus and resulted in a large flow reduction in the outlet river. After several spring months of restricted water discharge, a catastrophic breakout flood burst from four new portals: three on the west side and one on the top of the ice above the terminus, just east of the normal river portal. This flood event mobilized considerable debris from along the west side and front of the glacier, the lateral ablation valley, and the nearby Neoglacial and Little Ice Age moraines on the west side (Figs 2 and 8). After a number of months when all the impounded water was drained from the subglacial reservoirs and additional ice-melt adjustments had occurred, the 
Table 4. Evaluation of efficiencies of sediment transfer from glaciers to rivers for Raikot, Shaigiri, and Sachen glaciers on Nanga Parbat. Qualitative measures of transfer efficiency: 2 - large, high, narrow, and/or common 1 -intermediate or mixed; 0 - small, low,wide, or rare; the numerical rating is included for the pupose of comparison. The comparative evaluation shows that summations of sediment supply efficiencies and valley and ice characteristic efficiencies do not effectively discriminate between the three glaciers, but that the efficiency summations associated with meltwater characteristics do differentiate the Sachen glacier from the other two.

\begin{tabular}{|c|c|c|c|c|c|c|}
\hline & Raikot & & Shaigiri & & Sachen & \\
\hline \multicolumn{7}{|l|}{ Sediment supply } \\
\hline Cold-based ice & Large & 2 & Small & 0 & Small & 0 \\
\hline Warm-based ice & Intermed. & 1 & Small & 0 & Large & 2 \\
\hline Firnfield sources & Large & 2 & Small & 0 & Small & 0 \\
\hline Avalanche sources & Large & 2 & Intermed. & 1 & Intermed. & 1 \\
\hline Debris sources & Large & 2 & Intermed. & 1 & Intermed. & 1 \\
\hline Supraglacial debris & Large & 2 & Large & 2 & Large & 2 \\
\hline Side slopes & Unveg. & 2 & Unveg. & 2 & Mixed & 1 \\
\hline Tectonics & Active & 2 & Intermed. & 1 & Intermed. & 1 \\
\hline Totals & & 15 & & 7 & & 8 \\
\hline \multicolumn{7}{|c|}{ Valley and ice characteristics } \\
\hline Terminus slope & Intermed. & 1 & Intermed. & 1 & Gentle & 0 \\
\hline Valley width & Intermed. & 1 & Wide & 0 & Narrow & 2 \\
\hline Ice velocity & High & 2 & High & 2 & Low & 0 \\
\hline Totals & & 4 & & 3 & & 2 \\
\hline \multicolumn{7}{|c|}{ Meltwater characteristics } \\
\hline Meltwater discharge & High & 2 & Low & 0 & Low & 0 \\
\hline Portal migration & Large & 2 & Intermed. & 1 & Small & 0 \\
\hline Outburst floods & $\begin{array}{l}\text { Common \& } \\
\text { large }\end{array}$ & 2 & Intermed. & 1 & Small & 0 \\
\hline Trunk river & None & 0 & Large & 2 & None & 0 \\
\hline Totals & & 6 & & 4 & & 0 \\
\hline
\end{tabular}

Raikot River returned to its pre-flood drainage portal on the west side of the glacier.

Raikot Glacier has almost no terminal moraine in its narrow valley, which suggests that the lateral movement of the Raikot River, coupled with other breakout floods, has efficiently removed much sediment from the terminal area. We postulate that the generally high ice velocities and efficient transfer of sediment to meltwater (Table 4) do not favor formation of rock glaciers in the Raikot valley.

\section{Shaigiri Glacier}

On the southwest side of Nanga Parbat the $6 \mathrm{~km}$ long Shaigiri Glacier accumulates in a high firnfield and ice-avalanche cirque basin at about 5000 $\mathrm{m}$ altitude below the ice caps of Mazeno Peak $(7120 \mathrm{~m})$. First mapped by Finsterwalder in 1936, at that time the glacier descended from its cirque in a steep icefall from $c .4850 \mathrm{~m}$ to $4300 \mathrm{~m}$ altitude over a distance of $c .1 .2 \mathrm{~km}$, before moving over a more gentle gradient $\left(8^{\circ}\right)$ to its terminus (Fig. 3 ). In 1996 we discovered that the main icefall, from $c$. $4500 \mathrm{~m}$ to $4300 \mathrm{~m}$, was now bare rock and had lost its direct connection to the ice fields above. This was confirmed later by examining SPOT satellite imagery from 1991 and 1996 that showed a complete ice fall in the earlier image and fully exposed rock in the latter (Fig. 3).

Kick (1962) had noted that the lower surface of Shaigiri Glacier had changed a good deal between 1934 and 1958 when he was there. At an altitude of $3900 \mathrm{~m}$ he found that the ice surface had downwasted $12.9 \mathrm{~m}$, and at $3800 \mathrm{~m}$ it had downwasted $4.0 \mathrm{~m}$, whereas near the terminus at $3700 \mathrm{~m}$ it thickened $2.1 \mathrm{~m}$. The terminus piled up a moraine rampart from about $3610 \mathrm{~m}$ to $3640 \mathrm{~m}$, and appeared to have raised the level of debris at the glacier bottom to produce what Kick (1962) referred to as a dam glacier. The overall form resembles that of a rock glacier, but the lack of transverse ridges and furrows, the tumbled uppermost surface of ice cliffs and debris piles, the low terminus angle, and other features described below show that the morphology of a 'classic' rock glacier (Wahrhaftig and Cox 1959) is lacking.

Shaigiri Glacier has forced the Rupal River against the south valley wall opposite (Fig. 10). 
Fig. 9. Shaigiri Glacier terminus in 1966 showing Rupal River on extreme left (west) and in the lower foreground. The main meltwater drainage occurs on the right (east) where a prominent fan has formed. Two light-colored areas of lacustrine sand and silt occur on the top of the terminus. The largest one on the left poured over the terminus slope in 1995 and eroded the lightcolored areas where no vegetation survived. Compare with Fig. 3 for locations.

Fig. 10. West Sango rock-glacier \# 1 on the right (south) side of Sachen Glacier in 1995. This lobe moved laterally into the ablation valley, blocked it, and caused formation of Sango Sar. Part of the East Sango rock glacier \# 2 occurs on the right side of the photograph.
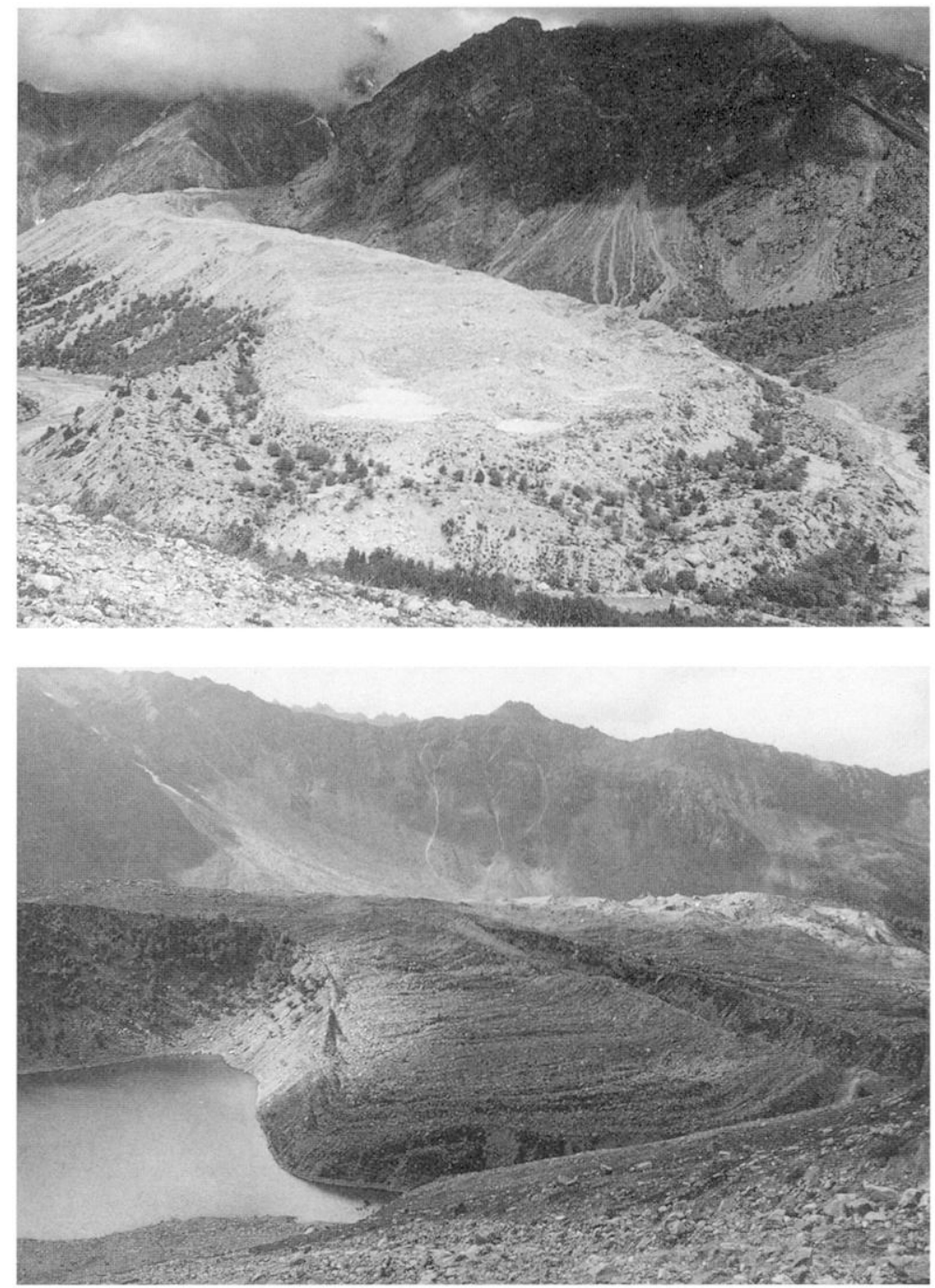

Fresh moraine remnants on the south bank show that the glacier has blocked the river in the past. Organic matter in sands impounded in slack water on the south bank dates at $170 \pm 200{ }^{14} \mathrm{C}$ years BP, suggesting that the glacier advanced significantly during the Little Ice Age and blocked the Rupal River.

The dominant meltwater pathway from the terminus of Shaigiri Glacier since the 1930s has been along the water-eroded left moraine on the north side of the ice from several small melt zones of exposed ice (Figs 3 and 9). A prominent debris fan has been developed laterally alongside the lateral moraine, with numerous intermittent exiting drainage- ways that cut though the lateral moraine at different points. Two different supraglacial water impoundments at the terminus have deposited thick lacustrine and fluvial sediments on the top of the terminus and caused subsequent breakout floods over the frontal moraine. The most recent flood occurred in the summer of 1995, cutting several channels and flushing out a minimum of $c .6000 \mathrm{~m}^{3}$ of sediment into the river (Fig. 9).

Velocity measurements on three transects close to the terminus of Shaigiri Glacier average $11.7 \mathrm{~cm}$ $\mathrm{day}^{-1}$ for transect 1 (Table 4), and a few millimeters to a few centimeters per day for the other two fur- 


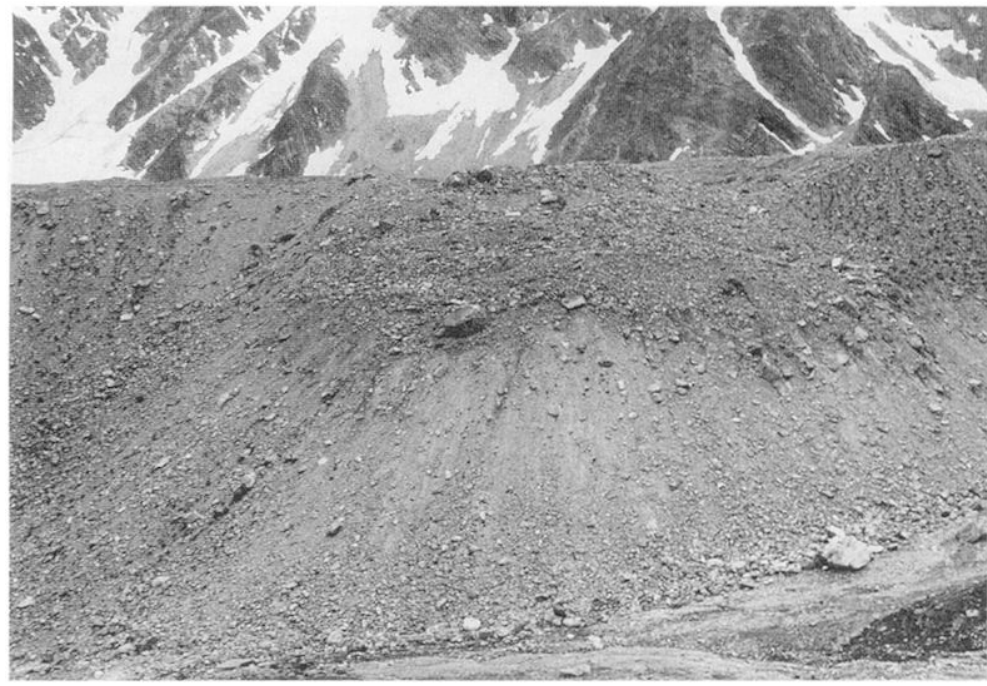

Fig. 11. Frontal view of Sachen rock glacier \# 3 showing a steep front at angle of repose in 1984 . Although foreshortened in this view, the lateral moraine of the main Sachen Glacier is visible on the left and the right, and several transverse ridges and furrows on the upper surface can be discerned. Meltwater was occurring midway up on the left side in 1984 . ther down the glacier. These velocities are similar to the Raikot Glacier and could, therefore, in the absence of a large outlet river, be expected to decrease sediment transfer potential by piling up thicker accumulations of debris at the terminus (Table 1). The known breakout floods and undercutting by the Rupal River, however, appear to considerably increase transfer efficiency (Table 4) so that debris does not greatly accumulate or form a rock glacier.

\section{Sachen Glacier}

This $8 \mathrm{~km}$-long glacier on the east slopes of the Nanga Parbat massif is nourished largely by ice-fall avalanches across an immense rocky cliff from the ice cap on Chongra Peak to the west (Fig. 4). A narrow ice fall from the small Gurikal Glacier to the southwest does still provide a more direct connection to high altitude firn fields. The main ablation zone of the glacier exists as a wide $(c .1 .5 \mathrm{~km})$, lowgradient $\left(c .5^{\circ}\right)$ mass with a digitate terminus. A number of rock glaciers have moved out from its lateral moraines, but not from the lowermost termini.

Sachen was first painted and described by Adolf Schlagintwiet in 1856 who reported the lateral moraine as standing 18-28 m high above Sango lake. Grove (1988) reported that Kick found the same moraine towering $180 \mathrm{~m}$ above the lake in 1958 and judged that the change was due to ice buildup around 1900. Since then the digitate or multiple tongues of the terminus have changed their position very little although the surface has dropped about $10 \mathrm{~m}$ in a number of places between the first survey in 1934 and the second in 1958. Both Mercer (1963) and Mayewski and Jeschke (1979) have noted that in terms of advance or retreat, of all of the glaciers on Nanga Parbat, Sachen Glacier is the only one with a nearly unchanging terminus, which is confirmed by our repeated observations since 1984.

Sachen rock glaciers. A number of unusual 'lateral moraine eruptions' (seitliche Gletscherausbruche) (Finsterwalder 1937) were originally mapped by Finsterwalder (1936) and have changed very little since then. These features occur at high angles to the dominant ice-flow direction, and thereby suggest either a spatial or a temporal disconnection between glacier flow and rock glacier motion, or both. It is unknown whether the internal ice of the rock glaciers is glacier ice or permafrost.

The West Sango rock-glacier lobe that impounded Sango lake was featured in Schlagintweit's 1856 water color so it was clearly already formed by that time, although it appears smaller than that of the present day. This landform has a classic rock-glacier form, with a large number of transverse ridges and furrows across it (Fig. 10).

In 1934 the upper top of the West Sango lobe was at an altitude of c. $3600 \mathrm{~m}$ where it broke through the lateral moraine, whereas the top of the terminus was $c .3500 \mathrm{~m}$. It has deflated somewhat since then, perhaps indicative of reduced avalanche input or 
Fig. 12. Rock glacier \# 4 at head of the ablation valley above Sango Sar on the south side of Sachen Glacier in 1984. On the right of the picture is the lateral moraine of Sachen and on the left is the rock wall of Bulan Kamm down which snow and ice avalanches travel. The rock glacier heads in the lowermost part of an avalanche chute, filled in its lower portions with glacier ice, and moves at right angles to the chute axis. The steep front at the angle of repose of the rock glacier is partially swept over by avalanche snow, some of which remains in this picture taken in midsummer.

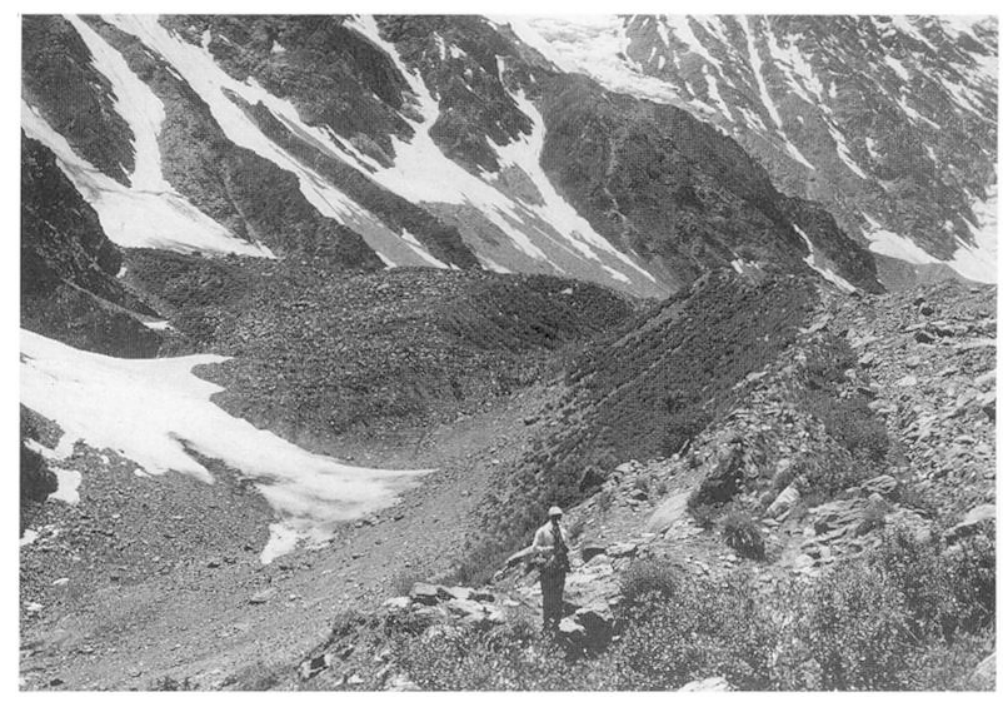

recent climatic warming. The oversteepened front has partially stabilized with vegetation since formation, although in a few places collapses have occurred. A second rock-glacier breakout of the moraine, the East Sango lobe (Fig. 7), occurs directly northeast of the West Sango lobe, but is not so prominent or well developed. Furthermore one of its lateral margins has been partially overrun by a halfmoon-shaped ridge of debris and ice, resembling a Kinematic wave. This ridge crest was first mapped and photographed by Finsterwalder (1937). This moraine crest was remapped by Kick 24 years later as having moved only $6-10 \mathrm{~m} \mathrm{a}^{-1}$ over the 24 years. This longterm average suggests ice velocities considerably less than those measured in the ablation zones of Raikot and Shaigiri Glaciers, but still considably more than the $\leq 1 \mathrm{~m} \mathrm{a}^{-1}$ characteristic of rock glaciers (Whalley and Martin 1992). A similar overriding glacier-ice lobe appears to be traveling down Sachen Glacier at the present time (Fig. 7).

A third rock-glacier breakout (Fig. 11) developed at an altitude of $c .3800 \mathrm{~m}$, almost directly across from the Gurikal icefall. It was $c .75 \mathrm{~m}$ wide at the top, $335 \mathrm{~m}$ wide at the bottom, $c .32 \mathrm{~m}$ high, extended out from the lateral moraine $c .150 \mathrm{~m}$, and has a front at the angle of repose of $36^{\circ}$. Small transverse ridges and furrows occur along its top, and water-saturated till from ice-melt was observed by one of us (JFS) on the northeast side in 1984 (Spencer 1985).

A fourth rock-glacier form at Sachen Glacier has moved laterally and parallel to the main ice motion and into the upper end of the ablation valley above Sango lake (Fig. 12). Its head region is the distal end of an ice-filled snow-avalanche chute that pours snow and ice onto the surface of Sachen Glacier. At right angles to this chute axis, the rock glacier has mobilized snow-avalanche debris that moved into the head of the ablation valley between the Sachen lateral moraine and the mountain wall. Finsterwalder (1936) mapped the form as $700 \mathrm{~m}$ long by $250 \mathrm{~m}$ wide, with crevassed glacier ice on its upper surface. Assuming that this cartography was accurate for the time, and that Finsterwalder is recognized as an otherwise highly accurate cartographer, by 1984 the feature had ablated a good deal, had concentrated debris on its upper surface, and was quite different in that it no longer showed any ice on its surface. A number of transverse ridges and furrows now run across the upper surface of the form and a steep terminus at the angle of repose shows its affinity to classic rock-glacier morphology. This seems to represent rare documentation of a glacier tongue evolving into a rock glacier.

Motive mechanisms for these unusual rock-glacier breakouts containing glacier ice might relate to irregular large ice avalanches that, in times of ice buildup of the main glacier, apply differential ice pressure to the high and steep lateral moraines. Alternatively, buildup of permafrost in moraines at certain locations could also account for the unusual rock-glacier configuration. The pressure would then cause the ice to flow perpendicular to the moraine and produce the characteristics of a rock gla- 
cier. With its very inefficient ice to meltwater transfer (Table 4), it seems likely that Sachen Glacier occasionally responds to spatially and temporally localized deliveries of ice mass by. breakouts of lateral ice. Once formed they tend to remain as a largely static rock-glacier form, although ice meltout may reduce the surface height.

\section{Conclusion}

The debris-covered glaciers of Nanga Parbat in the western Himalaya that were studied for this report have each had diverse histories, but share similar morphologies. Raikot, Shaigiri, and Sachen Glaciers all receive large quantities of debris on their surfaces that is carried down-glacier and concentrated at the glacier termini. Most of the large glaciers on Nanga Parbat, except Sachen have moderate to strong debris-transfer efficiencies into highenergy fluvial systems that remove much material from the termini and forefields of the glaciers.

Sachen Glacier, which has generally inefficient transfer mechanisms, (Table 4), is the the only one of the group that has generated rock glaciers. A motive mechanism is suggested in which buildup of thick debris covers that are not efficiently removed, can result in rock-glacier forms. Whether or not the Sachen rock glaciers have internal glacier ice or permafrost is unknown, but observations over $c$. 50 years do document the transition of an ice glacier to a rock glacier. We propose that the mechanism of this transition is the reduction of the sediment transfer efficiency of the glacier. A reduced ice velocity and a decrease in the rate of debris removal from the glacier can lead to buildup of debris and the development of a rock glacier in certain areas. Once formed, the rock-glacier morphology may become a persistent landform, except for slow movement and minor downwasting because of internal ice melt.

\section{Acknowledgements}

This work was funded by parts of grants from the University Committee on Research at the University of Nebraska at Omaha, the Smithsonian Institution, Fulbright, National Geographic Society, and the National Science Foundation (Grant No. EAR 9418839). We would like to thank M. Karim and M. Shaqil from Hunza for their assistance and all the students who worked with us in the field: A. Elmore, A. Jacobson, P. Nieland, D. Norsby, W. Phillips, R. Scheppy, A. Schmidt, M. Spencer and
J. Ward. M. Barton provided excellent cartography. E. Steig, D. Burbank, and anonymous reviewers provided excellent criticisms that greatly improved the manuscript, but the writers take full responsibility for the interpretations presented herein.

John F. Shroder and Michael P. Bishop, Department of Geography and Geology, University of Nebraska at Omaha, Omaha NE 68182, USA.

Luke Copland, Department of Geology, University of Alberta, Edmonton, AB T6G 2E3, Canada.

Valerie F. Sloan, INSTAAR, University of Colorado, Boulder, CO 80309, USA.

\section{References}

Barsch, D., 1996: Rockglaciers. Springer. Berlin.

Bishop, M.P., Shroder, J.F. Jr and Hickman, B.L., 1999: SPOT panchromatic imagery and neural networks for information extraction in a complex mountain environment. Geocarto International, 14: 17-26.

Bishop, M.P., Shroder, J.F. Jr and Ward, J.L., 1995: SPOT multispectral analysis for producing supraglacial debris-load estimates for Batura Glacier, Pakistan. Geocarto International, 10(4):81-90.

Bishop, M.P., Shroder, J.F. Jr, Hickman, B.L. and Copland, L., $1998 \mathrm{~b}:$ Scale-dependent analysis of satellite imagery for characterization of glacier surfaces in the Karakoram Himalaya. Geomorphology, 21:217-232.

Bishop, M.P., Shroder, J.F. Jr, Sloan, V.F., Copland, L. and Colby, J.D., 1998a: in press. Remote sensing and GIS science and technology for studying lithospheric processes in a mountain environment. Geocaro International.

Finsterwalder, R., 1936: Karte der Nanga Parbat Gruppe, 1:50,000. Republished 1980 by Alpenvereinskartographie vom Österreichischen Alpenverein.

- 1937: Die Gletscher des Nanga Parbat: Glaziologische Arbeiten der Deutschen Himalaya-Expedition 1934 und ihre Ergebnisse. Zeitschrift für Gletscherkunde, 25:57-108.

Gardner, J.S., 1986: Recent fluctuations of Rakhiot Glacier, Nanga Parbat, Punjab Himalaya, Pakistan. Journal of Glaciology, 32:527-529.

Gardner, J.S. and Jones, N.K., 1993: Sediment transport and yield at the Raikot Glacier, Nanga Parbat, Punjab Himalaya. In: Shroder, J.F. Jr, (ed.): Himalaya to the sea. Routledge. London. 184-197.

Giardino, J.R., Shroder, J.F. Jr and Vitek, J.D., 1987. Rock Glaciers. Allen \& Unwin. Boston.

Gong, P. and Chen, J., 1996: Mapping, ecological land systems and classification uncertainties from digital elevation and forest-cover data using neural networks. Photogrammetric Engineering and Remote Sensing, 62 (11): 1249-1260.

Grove, J.M., 1988: The Little Ice Age. Methuen. London.

Harbor, J., Sharp, M., Copland, L., Hubbard, B., Nienow, P. and Mair, D., 1997: The influence of subglacial drainage conditions on the velocity distribution within a glacier cross section. Geology, 25:739-742.

Hepner, G.F., Logan, T., Ritter, N. and Bryant, N., 1990: Artificial neural network classification using a minimal training set: 
comparison to conventional supervised classification. Photogramnmetric Engineering and Remote Sensing, 56:469-473.

Kick, W. 1962: Variations of some central Asiatic Glaciers. In: Variations of the regime of existing glaciers. Commission of Snow and Ice. IAHS Publication 58. 223-229.

- 1980: Material for a glacier inventory of the Indus drainage basin-the Nanga Parbat massif. World Glacier Inventory. Proceedings of the Reideralp Workshop, 1978. IAHS-AISH Publication 126. 105-109.

Mattson, L.E. and Gardner, J.S., 1989: Energy exchanges and ablation rates on the debris-covered Rakhiot [Raikot] Glacier. Zeitschrift für Gletscherkunde und Glazialgeologie. 25(1): 17-32.

Mattson, L.E., Gardner, J.S. and Young, G.J., 1993: Ablation on debris covered glacier, Punjab, Himalaya. Snow and Glacier Hydrology. IAHS Publication No. 218. 289-296.

Mayewski, P.A. and Jeschke, P.A., 1979: Himalayan and transHimalayan glacier fluctuations since AD 1812. Arctic and Alpine Research, 11:267-287.

Mercer, J.H., 1963: Glacier variations in the Karakoram. Glaciological Notes 14. World Data Center on Glaciology. Tacoma, WA. 19-33.

- 1975a: Glaciers of the Karakoram. In: Field, W.O. (ed.): Mountain glaciers of the Northern Hemisphere. 371-409.

- 1975b: Glaciers of the Himalaya. In: Field, W.O. (ed.): Mountain glaciers of the Northern Hemisphere. 411-447.

Pillewizer, W., 1956: Der Rakhiot-Gletscher am Nanga Parbat im Jahre 1954. Zeitschrift für Gletscherkunde und Glazialgeologie, 3:181-194.

Rumelhart, D.E. and McClelland, J.L., 1986: Parallel distributed processing: exploration in the microstructure of gognition. MIT Press. Cambridge, MA.

Shroder, J.F., Jr, Bishop, M.P., Quade, J., Phillips, W., Nieland, P.H. and Schmidt, A.M., 1996: Dendrogeomorphology and denudation efficiency, Nanga Parbat Himalaya. 11th Himalaya-Karakoram-Tibet Workshop. Flagstaff, AZ. 135-136.

Shroder, J.F., Jr, Bishop, M.P. and Scheppy, R., 1998: Catastrophic flood flushing of sediment, western Himalaya, Pakistan. In: Kalvoda, J. and Rosenfeld, C.L. (eds): Geomorphological hazards in high mountains areas. Kluwer Academic Publishers. Dordrecht.

Spencer, M.C., 1985: Geomorphologic analysis of the Sachen Glacier, Nanga Parbat, Pakistan. Unpublished senior thesis, Department of Geography and Geology, University of Nebraska at Omaha.

Sui, D., 1994: Recent applications of neural networks for spatial data handling. Canadian Journal of Remote Sensing, 20(4):368-379.

Vitek, J.D. and Giardino, J.R. 1987: Rock glaciers: a review of the knowledge base. In: Giardino, J.R.,Shroder, J.F. Jr and Vitek, J.D. (eds): Rock Glaciers. Allen \& Unwin. Boston. 1-26.

Wahrhaftig, C. and Cox, A., 1959: Rock glaciers in the Alaska Range. Geological Society America Bulletin, 70:383-436.

Whalley, B. and Martin, H. E., 1992: Rock glaciers: II models and mechanisms. Progress in Physical Geography, 16(2):127186.

Manuscript received April 1997, revised and accepted Febr. 1999. 